\title{
Improving Student Learning Outcomes using Image Media on Learning Science Materials About Sense Tools in SDN 2 Tuksongo Students
}

\section{Tri Setyorini}

SD Negeri 2 Tuksongo

Isetyorinitri165@gmail.com

\section{Article History}

accepted $14 / 11 / 2020$

\begin{abstract}
outcomes for fourth grade students of SDN 2 Tuksongo in science learning material about tools. sense. The number of students consists of 15 people. This research is an action research a class consisting of two cycles and 4 meetings. Research design following the research stage which refers to the modification of the Kemmis and Mc diagram.Taggart, namely 1) planning action, 2) executing action, 3) observation, and 4) Reflection. The data collection technique used was the teacher's observation sheet, student observation sheets, student worksheets, and student learning outcomes tests. Result research shows that there is an increase in learning outcomes, from cycle I to cycle II. This increase is evidenced by the results of the analysis of student learning outcomes tests obtained in cycle I are: students who completed 11 of 15 students or classical completeness percentage of $73.3 \%, 68 \%$ classical absorption, and activity students in either category. In cycle II students who completed 13 of 15 students or classical completeness $86.7 \%$, classical absorption of $82 \%$, and student activities are in very good category. Based on the research results indicate that The use of image media can improve the learning outcomes of fourth grade students of SDN 2 Tuksongo in science learning material about the senses..
\end{abstract}

Keywords: Learning outcomes, image media

\begin{abstract}
Abstrak
Penelitian ini dilatarbelakangi rendahnya hasil belajar siswa pada materi alat-alat indera terbukti dari rata-rata hasil belajar yaitu 60 . Penelitian ini bertujuan untuk membuktikan bahwa penggunaan media gambar dapat meningkatkan hasil belajar siswa kelas IV SDN 2 Tuksongo pada pembelajaran IPA materi tentang alat-alat indera. Jumlah siswa terdiri dari 15 orang. Penelitian ini adalah penelitian Tindakan kelas yang terdiri atas dua siklus dan 4 kali pertemuan. Rancangan penelitian mengikuti tahap penelitian yang mengacu pada modifikasi diagram Kemmis dan Mc.Taggart, yaitu 1) Perencanaan tindakan, 2) Pelaksanaan tindakan, 3) Observasi, dan 4) Refleksi. Teknik pengumpulan data yang digunakan adalah lembar observasi guru, lembar observasi siswa, lembar kerja siswa, dan tes hasil belajar siswa. Hasil penelitian menunjukkan bahwa terjadi peningkatan hasil belajar, dari siklus I ke siklus II. Peningkatan tersebut dibuktikan dengan hasil analisis tes hasil belajar siswa yang diperoleh pada siklus I adalah: siswa yang tuntas 11 dari 15 siswa atau persentase ketuntasan klasikal sebesar 73,3\%, daya serap klasikal $68 \%$, serta aktivitas siswa dalam kategori baik. Pada siklus II siswa yang tuntas 13 dari 15 siswa atau ketuntasan klasikal 86,7\%, daya serap klasikal sebesar $82 \%$, serta aktivitas siswa berada dalam kategori sangat baik. Berdasarkan hasil penelitian menunjukkan bahwa penggunaan media gambar dapat meningkatkan hasil belajar siswa kelas IV SDN 2 Tuksongo pada pembelajaran IPA materi tentang alat-alat indera.
\end{abstract}

Kata kunci: Hasil belajar, media gambar

Social, Humanities, and Education Studies (SHEs): Conference Series https://jurnal.uns.ac.id/shes

p-ISSN 2620-9284 e-ISSN 2620-9292 


\section{PENDAHULUAN}

Upaya untuk meningkatkan hasil belajar siswa, diantaranya dapat dilakukan melalui upaya memperbaiki proses pembelajaran. Namun pada kenyataannya, upaya tersebut terkadang ditemukan suatu permasalahan, seperti hasil temuan dalam pembelajaran bidang studi IImu Pengetahuan Alam (IPA) siswa kelas IV SDN 2 Tuksongo menunjukkan bahwa rendahnya minat dan keaktifan belajar IPA antara lain tampak pada rendahnya hasil belajar IPA, khususnya pada materi alat-alat indera, dimana siswa masih kesulitan membedakan bagian-bagian alat indera dan fungsi bagian-bagian alat-indera. Hal tersebut disebabkan guru sering menggunakan metode

yang sifatnya satu arah atau metode ceramah dan tidak menggunakan media yang membantu penyampaian materi, sehingga siswa hanya mendengar dan mencatat. Hal ini merupakan salah satu indikator bahwa pembelajaran IPA di sekolah belum maksimal. Rendahnya hasil belajar siswa pada materi alat-alat indera terbukti dari ratarata hasil belajar yaitu 60. Hasil ini belum mencapai nilai KKM IPA yang ditetapkan yaitu 70 . Pernyataan tersebut dibuktikan dengan hasil tes awal yang dilakukan guru sebelum melakukan penelitian. Hasil analisis secara ringkas dapat dilihat pada Tabel 1.

Tabel 1. Daftar nilai mata pelajaran IPA Kelas IV SDN 2 Tuksongo

\begin{tabular}{cccc}
\hline Kategori & Nilai & Ketuntasan & Jumlah siswa \\
\hline Jumlah siswa yang Tuntas & $\geq 7$ & \multirow{2}{*}{$53,3 \%$} & 8 \\
Jumlah siswa yang tidak tuntas & $<7$ & & 7 \\
Jumlah siswa & & & 15 \\
\hline
\end{tabular}

Rata-rata hasil belajar yang masih rendah, dapat dipengaruhi oleh siswa yang kurang aktif dan kurang bersemangat dalam mengikuti mata pelajaran khususnya pada mata pelajaran IPA. Hal ini disebabkan penggunaan pendekatan, metode, dan strategi yang tidak tepat serta tidak disertai media pembelajaran dalam suatu proses pembelajaran diasumsikan merupakan salah satu faktor penentu kurang maksimalnya pencapaian tujuan belajar di sekolah. Pelatihan-pelatihan yang diberikan oleh guru sebagai pengelola pembelajaran dalam memberikan penjelasan terhadap materi ajar yang terkait cenderung masih menekankan pada metode ceramah. Akibatnya siswa tidak memperoleh kesempatan untuk belajar mandiri secara aktif, maka dari itu hasil belajar siswa mengalami penurunan.

Berdasarkan fenomena tersebut, maka diperlukan wahana yang dapat mengatasi masalah ini berupa media pembelajaran yang diharapkan dapat membantu siswa memahami konsep dalam pembelajaran. Media yang cocok digunakan di tingkat Sekolah Dasar adalah media gambar karena media ini dapat menarik perhatian siswa. Berkenaan dengan pernyataan tersebut, penulis termotivasi untuk melakukan penelitian tindakan berupa penggunaan media gambar dalam pembelajaran IPA, khususnya pada materi alat-alat indera manusia yang diharapkan dapat meningkatkan hasil belajar kelas IV SDN 2 Tuksongo. Penggunaan media gambar sederhana akan membantu guru dalam penyampaian yang beragam, pembelajaran menjadi lebih jelas dan menarik, proses pembelajaran menjadi lebih interaktif, efisiensi dalam waktu dan tenaga. Berdasarkan latar belakang, maka penulis terdorong untuk melakukan penelitian dengan judul "Peningkatan Hasil Belajar Siswa Kelas IV SDN 2 Tuksongo melalui Media Gambar pada Pembelajaran IPA Materi tentang Alat-Alat Indera".

Alasan peneliti memilih judul penggunaan media gambar adalah sebagai berikut:

Memudahkan guru menyampaikan materi alat-alat indera manusia agar siswa dapat melihat secara jelas bagian-bagian alat indera. 
Belum tersedianya alat peraga atau KIT IPA khususnya KIT anatomi alat-alat indera manusia, sehingga guru harus memilih penggunaan media yang mudah dibuat oleh guru sebagai bentuk kreatifitasnya untuk mengatasi masalah yang dihadapi dalam pembelajaran.

Belum pernah diterapkan penggunaan media gambar dalam pembelajaran alat indera manusia, karena hanya menggunakan gambar pada buku yang kadang gambar di buku terlalu kecil ukurannya dan kurang jelas. Selain itu, jumlah buku siswa yang terbatas, sehingga guru biasanya membagi siswa dalam bentuk kelompok berdasarkan jumlah buku yang ada.

\section{METODE}

Penelitian ini dilaksanakan selama 2 (dua) siklus dan masing-masing siklus dilakukan sebanyak 2 (dua) kali pertemuan, yaitu siklus I terdiri dari pertemuan 1 dan pertemuan 2. Siklus II juga terdiri dari 2 (dua) pertemuan dengan alokasi waktu setiap pertemuan adalah 2 × 35 menit. Jenis penelitian ini adalah Penelitian Tindakan Kelas (PTK), mengacu pada modifikasi diagram yang dikemukakan oleh Kemmis dan Mc Taggart (Wiriaatmadja, 2008:66). Tiap siklus dilakukan beberapa tahap, yaitu: 1) perencanaan tindakan, 2) pelaksanaan tindakan, 3) observasi, dan 4) refleksi.

Penelitian ini telah dilaksanakan di SDN 2 Tuksongo pada bulan Agustus 2018. Subyek penelitian ini adalah siswa kelas IV tahun ajaran 2017/2018, yang berjumlah 15 orang terdiri dari 8 siswa perempuan dan 7 siswa laki-laki. Observasi ini dilakukan pada saat penelitian atau dalam proses pembelajaran penggunaan media gambar. Kegiatan observasi dibantu oleh seorang pengamat atau observer untuk mengamati semua aktivitas peneliti dan aktivitas siswa dalam proses pembelajaran. Hasil observasi dicatat dalam lembaran observasi aktivitas siswa yang telah disediakan serta mendokumentasikan semua kegiatan sebagai bukti telah dilaksanakannya penelitian tindakan kelas. Hasil pengamatan ini berupa data observasi untuk direfleksi sehingga pengamatan yang dilakukan dapat menceritakan keadaan sesungguhnya mengenai efektivitas penggunaan media gambar terhadap hasil belajar siswa. Kegiatan yang dilakukan pada tahap ini adalah menganalisis data yang diperoleh pada tahap observasi. Berdasarkan hasil analisa data dilakukan refleksi guna melihat kekurangan dan kelebihan yang terjadi saat pembelajaran diterapkan. Kekurangan dan kelebihan dijadikan acuan untuk merencanakan siklus berikutnya. Pengumpulan data dilakukan melalui dua cara, yaitu tes dan observasi. Analisis data kualitatif dalam penelitian ini dilakukan sesudah pengumpulan data. Adapun tahap-tahap kegiatan analisis data kualitatif menurut Miles dan Huberman (dalam Iskandar, 2009:75) adalah reduksi, penyajian data dan verifikasi.

Hasil Penelitian Siklus I

\section{HASIL DAN PEMBAHASAN}

Pelaksanaan kegiatan belajar mengajar untuk siklus I dilaksanakan pada tanggal 6 Agustus 2018 dengan jumlah siswa 15 orang. Selanjutnya proses belajar mengajar mengacu pada rencana pelajaran yang telah dipersiapkan. Selesai pelaksanaan kegiatan pembelajaran tindakan siklus I dengan penggunaan media gambar, kegiatan selanjutnya adalah pemberian tes hasil balajar untuk mengetahui hasil belajar siswa. Bentuk tes hasil belajar yang diberikan adalah uraian dengan jumlah soal 4 butir yang disertai gambar alat indera mata dan telinga. Secara ringkas hasil analisis tes siklus I dapat dilihat pada Tabel 2. 
SHEs: Conference Series 3 (3) (2020) $1336-1342$

Tabel 2. Analisis Tes Hasil Belajar Siklus I

\begin{tabular}{clc}
\hline No. & \multicolumn{1}{c}{ Aspek Perolehan } & Hasil \\
\hline 1. & Skor tertinggi & 8 \\
2. & Skor terendah & 4 \\
3. & Jumlah Siswa & 15 \\
4. & Banyak siswa yang tuntas & 11 \\
5. & Banyak siswa yang tidak tuntas & 4 \\
6. & Persentase tuntas klasikal & $73,3 \%$ \\
7. & Persentase daya serap klasikal & $68 \%$ \\
8. & Rata-rata hasil belajar & 6,8 \\
\hline
\end{tabular}

Berdasarkan Tabel 2, dapat dijelaskan bahwa nilai rata-rata hasil belajar siswa adalah 6,8 dan ketuntasan belajar klasikal mencapai $73,3 \%$ atau ada 11 siswa dari 15 siswa sudah tuntas belajar. Hasil tersebut menunjukkan bahwa pada siklus I, secara klasikal siswa belum tuntas belajar, karena siswa yang memperoleh nilai $\geq 7$ hanya sebesar $73,3 \%$ lebih kecil dari presentase ketuntasan yang dikehendaki yaitu sebesar $80 \%$. Hal ini disebabkan karena masih ada beberapa siswa yang kurang serius mengikuti pelajaran, ada siswa yang kurang aktif saat proses tanya jawab dan pemberian tugas mengerjakan LKS.

Hasil Penelitian Siklus II

Pelaksanaan kegiatan belajar mengajar untuk siklus II dilaksanakan pada tanggal 20 dan 27 Agustus 2018 dengan jumlah siswa 15 siswa. Selanjutnya proses pembelajaran mengacu pada rencana pelajaran yang telah dipersiapkan. Pengamatan (observasi) dilaksanakan bersamaan dengan pelaksanaan pembelajaran.

Selesai pelaksanaan kegiatan pembelajaran tindakan siklus II dengan penggunaan media gambar, kegiatan selanjutnya adalah pemberian tes hasil balajar untuk mengetahui hasil belajar siswa. Bentuk tes hasil belajar yang diberikan adalah uraian dengan jumlah soal 3 butir. Secara ringkas hasil analisis tes siklus II dapat dilihat pada Tabel 3 .

Tabel 3. Analisis Tes Hasil Belajar Siklus II

\begin{tabular}{clc}
\hline No. & \multicolumn{1}{c}{ Aspek Perolehan } & Hasil \\
\hline 1. & Skor tertinggi & 10 \\
2. & Skor terendah & 6 \\
3. & Jumlah Siswa & 15 \\
4. & Banyak siswa yang tuntas & 13 \\
5. & Banyak siswa yang tidak tuntas & 2 \\
6. & Persentase tuntas klasikal & $86, \% 82$ \\
7. & Persentase daya serap klasikal & $\%$ \\
8. & Rata-rata hasil belajar & 8,2 \\
\hline
\end{tabular}

Berdasarkan Tabel 3. dapat dijelaskan bahwa nilai rata-rata hasil belajar siswa pada siklus II mengalami peningkatan yakni 8,2 dan ketuntasan belajar mencapai $86,7 \%$ atau ada 13 siswa dari 15 siswa tuntas belajar. Hasil tersebut menunjukkan bahwa pada siklus kedua secara klasikal siswa telah tuntas belajar, karena siswa yang memperoleh nilai $\geq 7$ telah mencapai $86,7 \%$ lebih dari presentase ketuntasan yang dikehendaki yaitu sebesar $80 \%$.

Efektivitas dan efisien belajar individu di sekolah sangat bergantung kepada peran guru. Salah satunya penggunaan media pembelajaran harus sesuai dengan materi yang diajarkan. Dalam memilih media untuk pembelajaran, guru sebenarnya tidak hanya cukup mengetahui tentang kegunaan, nilai, serta landasannya, tetapi juga harus mengetahui bagaimana cara menggunakan media tersebut (Syamsudin, 2003). 
Penggunaan media gambar dalam pembelajaran sesuai dengan hasil penelitian yang dilaksanakan dalam dua siklus dapat meningkatkan hasil belajar pada pokok bahasan alat indera manusia dalam pembelajaran IPA siswa kelas IV SDN 2 Tuksongo. Hal tersebut didukung teori yang dikemukakan oleh Made (2008:2) yaitu dalam pembelajaran di sekolah dasar media gambar sangat baik digunakan dan diterapkan dalam proses belajar mengajar sebagai media pembelajaran karena media gambar ini cenderung sangat menarik hati siswa sehingga akan muncul motivasi untuk lebih ingin mengetahui tentang gambar yang dijelaskan dan gurupun dapat

menyampaikan materi dengan optimal melalui media gambar tersebut. Dari semua aktivitas yang dilaksanakan baik aktivitas guru, aktivitas siswa, dan analisis tes hasil belajar siswa setiap akhir siklus I dan siklus II, tampak terjadi peningkatan yang signifikan dari sebelum dilakukan penelitian.

Peningkatan aktivitas guru, aktivitas siswa, dan hasil belajar terjadi karena kekurangan yang terdapat pada siklus I yang digambarkan pada hasil refleksi dapat diminimalisir berdasarkan rekomendasi yang diajukan oleh teman sejawat (observer) bersama dengan guru (peneliti). Masing-masing alasan terjadinya peningkatan hasil belajar dengan menggunakan media gambar dalam pembelajaran IPA materi alat-alat indera manusia dapat dijelaskan sebagai berikut.

Aktivitas guru dalam setiap pertemuan menunjukkan peningkatan yang dapat mencapai indikator kinerja, sehingga dapat dikatakan aktivitas guru pada pelaksanaan pembelajaran menurut observer dalam kategori sangat baik. Hal tersebut berarti bahwa guru sebagai peneliti dapat melaksanakan tugas dan tanggung jawabnya dengan sangat baik, yaitu a) sebagai pengajar; b) sebagai pembimbing; dan c) sebagai administrator kelas. Sesuai dengan pendapat Umar (1994) yang menyatakan bahwa guru memainkan multi peran dalam proses pembelajaran yang diselenggarakan dengan tugas yang amat bervariasi. Guru berperan sebagai manager, pemandu, organisator, koordinator, komunikator, fasilitator, dan motivator proses pembelajaran.

Sebagai pengajar melakukan kegiatan: (a) menyusun rencana pelaksanaan pembelajaran sesuai dengan langkah-langkah penelitian; (b) guru sebagai pembimbing dapat membimbing siswa yang masih kesulitan dalam memahami pembelajaran IPA, membimbing siswa dalam menjelaskan gambar yang diperlihatkan, dan membimbing siswa menyelesaikan tugas dengan baik. (c) guru sebagai administrator kelas, menyiapkan media gambar yang bervariasi dan menarik minat belajar siswa dan menyiapkan LKS untuk melatih kemampuan siswa setelah diberikan materi pembelajaran.

Data observasi terhadap aktivitas siswa siklus I berupa lembar penilaian berada dalam kriteria cukup pada pertemuan pertama dan kriteria baik pada pertemuan kedua. Kriteria tersebut sudah mencapai indikator keberhasilan namun perlu perbaikan, disebabkan masih ada kekurangan untuk ditingkatkan. Hal yang dianggap kurang pada "Aspek aktif bertanya tentang hal-hal yang belum jelas dan aktif menjawab pertanyaan guru", siswa kurang aktif bertanya, padahal ketika guru bertanya banyak siswa yang tidak menjawab dan ada pula yang menjawab tetapi kurang tepat. Oleh sebab itu, pada siklus berikutnya, guru memotovasi siswa yang kurang aktif dengan cara meminta untuk menjelaskan gambar di depan temantemannya agar diketahui siswa mana yang belum memahami penjelasan guru.

Pada siklus II, penilaian hasil observasi kegiatan siswa lebih baik dari siklus I. Setiap aspek penilaian dilaksanakan dengan baik sesuai urutannya, seperti saat guru menyampaikan materi, siswa terlihat tenang. Dalam hal ini, siswa diarahkan untuk memperhatikan penjelasan guru agar nantinya mampu menjawab pertanyaan ketika guru memberikan kesempatan untuk menjelaskan gambar dan menyelesaikan LKS. Bentuk motivasi yang diberikan guru adalah menampilkan beberapa gambar alat-alat indera berwarna dan menarik perhatian siswa, kemudian memberikan kesempatan 
kepada siswa untuk menjelaskan secara singkat materi pada media gambar yang ditampilkan secara bergantian, sehingga siswa lebih memahami pelajaran.

Setiap aspek tindakan menunjukkan peningkatan dan dapat dikatakan aktivitas siswa mengikuti pembelajaran, rata-rata dalam kriteria sangat baik. Penggunaan media dalam proses pembelajaran akan lebih menarik, sebab siswa tak hanya mendengar, tetapi juga melihat penerapan konsep yang dipelajari. Hal tersebut sesuai dengan pendapat Nana (2007) yang menyatakan bahwa media pembelajaran dapat: (a) meningkatkan minat belajar siswa, (b) kegiatan pembelajaran akan lebih menarik perhatian siswa sehingga dapat menumbuhkan minat siswa, dan (c) bahan pembelajaran akan lebih jelas dan bermakna sehingga lebih mudah dipahami siswa dan memungkinkan siswa untuk menguasai tujuan pembelajaran yang lebih baik.

Media gambar sebagai perantara dalam proses pembelajaran menggambarkan atau memfisualisasikan materi ajar yang bertujuan untuk memudahkan siswa mengerti dan memahami secara optimal mengenai materi atau bahan ajar yang di berikan guru pada siswa.

Hasil belajar adalah prestasi belajar yang dicapai siswa dalam proses kegiatan belajar mengajar. Dalam penelitian ini, hasil belajar diukur dengan menggunakan tes hasil belajar yang diberikan setelah proses pembelajaran dengan menggunakan media gambar pada materi alat-alat indera manusia.

Rata-rata hasil belajar yang diperoleh pada siklus I adalah 6,8 dengan ketuntasan klasikal $73,3 \%$ dan pada siklus II meningkat menjadi 8,2 dengan ketuntasan klasikal $86,7 \%$. Hasil belajar siswa mengalami peningkatan dari sebelum penelitian sampai pada siklus II. Siklus I menuntaskan siswa sebanyak 11 dari 15 jumlah siswa atau terdapat 4 siswa yang belum tuntas menyelesaikan soal dengan baik. Sedangkan hasil yang diperoleh pada siklus II lebih baik daripada hasil silklus I.

Peningkatan ini terjadi karena siswa yang nilainya rendah diberikan bimbingan setelah jam pelajaran. Hasil refleksi pada siklus I dijadikan acuan untuk mendapatkan hasil yang lebih baik pada siklus berikutnya.

Usaha yang dilakukan guru untuk memperoleh hasil yang lebih baik yaitu pada awal pertemuan siklus II, guru melakukan apersepsi atau mengingatkan kembali materi pada siklus I dan tanya jawab tentang bagian-bagian alat indera mata dan telinga. Selain itu, guru memberi kesempatan kepada siswa secara merata untuk tampil di depan menyebutkan bagian-bagian gambar.

Sehubungan dengan uraian di atas, maka dapat dikatakan bahwa peluang keberhasilan belajar siswa tidak hanya dimiliki oleh siswa yang berkemampuan tinggi saja, tetapi siswa yang memiliki kemampuan sedang, dan bahkan untuk siswa yang memiliki tingkat kemampuan rendah juga dapat meraih keberhasilan.

Untuk memperoleh hasil pembelajaran yang diharapkan, maka dalam proses pembelajaran semestinya menggunakan media yang memungkinkan keterlibatan siswa secara maksimal. Dengan demikian dapat dikatakan bahwa penggunaan media gambar dalam pembelajaran IPA pada materi alat-alat indera dapat meningkatkan hasil belajar siswa kelas IV SDN 2 Tuksongo.

\section{SIMPULAN}

Berdasarkan hasil analisis data penelitian dapat disimpulkan bahwa Aktivitas guru dan kegiatan pembelajaran dengan menggunakan media gambar menunjukkan adanya peningkatan. Guru dapat mengoptimalkan penggunaan media gambar pada proses pembelajaran. Hal ini dapat ditunjukkan dengan skor yang diperoleh pada hasil observasi rata-rata dalam kriteria sangat baik. Selain itu, aktivitas siswa Kelas IV SDN 2 Tuksongo dalam kegiatan pembelajaran dengan penggunaan media gambar pada materi alat-alat indera juga menunjukkan adanya peningkatan. 
Hal tersebut dapat dibuktikan dengan skor yang diperoleh yaitu dalam kriteria sangat baik. Penggunaan media gambar dapat meningkatkan kemampuan dan hasil belajar siswa kelas IV SDN 2 Tuksongo dalam pembelajaran IPA. Peningkatan ini dapat dilihat dari nilai persentase ketuntasan siklus I (73,3\%) dan siklus II mencapai $86,7 \%$.

Berdasarkan hasil penelitian tentang penggunaan media gambar pada pembelajaran IPA di kelas IV SDN 2 Tuksongo dengan saran penelitian ini sebagai berikut: (1) Bagi guru, sebaiknya menggunakan media gambar dalam pembelajaran, karena hal tersebut mempengaruhi hasil dan keberhasilan siswa dalam belajar; dan (2) Sekolah, diharapkan sekolah dapat menyediakan sarana dan prasarana penunjang keberhasilan pembelajaran.

\section{DAFTAR PUSTAKA}

Depdiknas. (2001). Manajemen Peningkatan Mutu Berbasis Sekolah. Jakarta: Dirjen Dikdasmen Direktorat SLTP.

Iskandar. (2009). Penelitian Tindakan Kelas. Jambi: Gaung Persada Press.

Made, I. T. (2008).Media Pembelajaran. Malang: Program Pasca Sarjana UNM

Nana, S. (2007). Teknologi Pengajaran. Bandung: Sinar Baru Algesindo

Syamsuddin, M. (2003). Psikologi Pendidikan. PT Rosda Karya.

Wiriaatmadja, R. (2008). Metode Penelitian Tindakan Kelas untuk Meningkatkan Kinerja Guru dan Dosen. Bandung: Remaja Rosda Karya. 